\title{
Anatomy of the Fund Management Industry
}

\author{
Dr. A Seetharaman ${ }^{1}$, Nitin Patwa ${ }^{1} \&$ Priyanka Suchdev ${ }^{1}$ \\ ${ }^{1}$ S P Jain School of Global Management - Dubai - Mumbai - Singapore - Sydney \\ Correspondence: Nitin Patwa, S P Jain School of Global Management - Dubai - Mumbai - Singapore - Sydney
}

Received: August 30, 2019

Accepted: September 20, 2019

Online Published: May 20, 2020

doi:10.5430/afr.v9n2p84

URL: https://doi.org/10.5430/afr.v9n2p84

\begin{abstract}
In the ever-growing realm of fund/investment management, there are various stakeholders involved. This paper has identified the significant factors that lead to issues coming up in the fund management industry within the working and operations. The paper consists of an extensive literature review from the perspective of the investor. It consists of a research framework that involves steps like factor recognition, problem recognition, possible solutions, and conclusion. The result of this study shows that various factors influence the working of these organizations, which include the organization hierarchy, fee structure, risk involved, information privacy, and level of professionalism. These factors affect the industry image as well as the level of trust in the minds of the investor. It can all very well translate to the betterment of an organization's workflow.
\end{abstract}

Keywords: investments, investors, investment management, fee structure, information privacy, risk

\section{Introduction}

With an ever-growing level of income across the globe, the fund management industry is facing a growth in the magnitude of funds getting allocated for investment. However, a large chunk of investors remains untapped. It is because there are many challenges that companies face while attracting individuals to invest with them (Andonov, A., Eichholtz, P., 2016). The challenges they face is what we will discuss through this paper.

The fund management industry acts as a link between seekers and providers. It is a marketplace where the parties with excess funds meet the parties in need of funds. Investments are made in exchange for a return that beats the level of inflation in the time horizon of investment. With the involvement of money, there comes a lot of rules and regulations that this industry is bound.

Over the years, it is seen that investors are now more aware of the impact their investments are having on the markets, economy, environment, and future trends. Investments today drive businesses across borders and are very important for their existence in society.

While the idea of letting someone else manage and invest one's money is an absurd concept, it is not entirely new. For years, considerable investment houses have been leading the excess funds that HNI individuals and large companies have (Hawley, J. P., \& Lukomnik, J., 2018). This gives them a chance to use professional investment management skills to generate returns for the investor while earning commissions or fees for themselves.

Countries with a well-established market attract investments from various platforms. Investments are made to help multiply money with the growth in these markets. Although there is a level of risk involved, the returns quoted are lucrative enough to get investments in.

Macro industry trends that are observed in the market are:

- A rise in AUM and a shift in the investor base

- Commercial cost pressures with maximization of distribution opportunities

- Big-data in investment processes

- Diversification of huge pools of assets

- Growth of global platforms

- Technology takes center-stage

- Customer engagement, data mining 
- Passive investment becoming core and s prefiltering

- New breeds of global and skilled management

- The emergence of robot-advisors in private wealth management

The asset management industry is highly competitive, with industry firms ranging from "pure-play" independent asset managers to diversified commercial banks, insurance companies, and brokerages that offer asset management services in addition to their core business activities. Traditional managers generally focus on long-only equity, fixed-income, and multi-asset investment strategies, while alternative asset managers focus on hedge funds, private equity, and venture capital strategies. Increasingly, the line between traditional and alternative managers has blurred.

Asset managers are increasingly offering other strategies beyond traditional market-cap-weighted exposures (Andonov, A., Eichholtz, P., 2016). One such approach is smart beta, which involves the use of simple, transparent, rules-based strategies as a basis for investment decisions.

Most asset management firms are owned privately. Portfolio managers who have personal capital invested in their firms or investment strategies are often viewed favorably by potential investors.

Asset managers who concentrate on individual investors typically club investment strategies through highly regulated pooled vehicles (e.g., mutual funds or exchange-traded funds). Institutional-focused managers usually package their investment strategies in less regulated and more customizable product structures (e.g., separately managed accounts and limited partnerships). Among the significant investment products offered by asset managers are mutual funds, separately managed accounts, exchange-traded funds, hedge funds, and private equity/venture capital funds (Hsiu-Lang Chen, 2000).

There are various doubts in the mind of the investor when they entrust a professional with their wealth for management purposes. They have some limitations and expectations when it comes to things like the level of risk involved, investment horizon returns expected, and covenants. Managers need to cautious while designing a portfolio for investors to make sure that wealth is always protected.

The literature review shows that the process of portfolio management is a long one, which includes construction, monitoring, and constant revision of the owner's portfolio to make sure the assets are generating maximum returns over time.

The research model in this paper is based upon an initial literature which led to identifying the seven most important factors that influence investment decisions when it comes to picking an investment company. The factors include front-end/back-end load, brokerage, outsourcing portfolios, corporate governance in the company, security and privacy of information, double agency problem, the behavioral approach of investors, fund performance measurement and comparison.

\section{Literature Review}

There is an existing body of literature that examines the current scenarios existing in the industry and how they will further develop. The literature review got structured according to the factors considered in this research. The structure of research followed gives information about the factors identified from the initial literature review, and the ensuing study gives insights into the various problems associated with each of these factors individually - the proposed solutions provided in the paper presented according to the current scenario in the market and industry.

\section{Research Methodology}

The research methodology centers on existing factors identified through an exhaustive literature review. A simple direct relationship between these seven factors is positioned in the research model.

Information for research was gathered from different sources of secondary data. Most data got collected from ProQuest, National Library e-Databases, Google Scholar, Ebscohost, and ISI Thomson.

Once the framework got set, the following order got followed:

1. Identifications of the factors

2. Problems and solutions

3. Discussion, analysis, and outcome

4. Research implications

5. Limitations and scope for future research 


\subsection{Research Framework and Recognition of Factors}

From the secondary data collected, the research framework got developed, as shown in Figure. 1. The impact of these factors is what we determine through further research of existing literature.

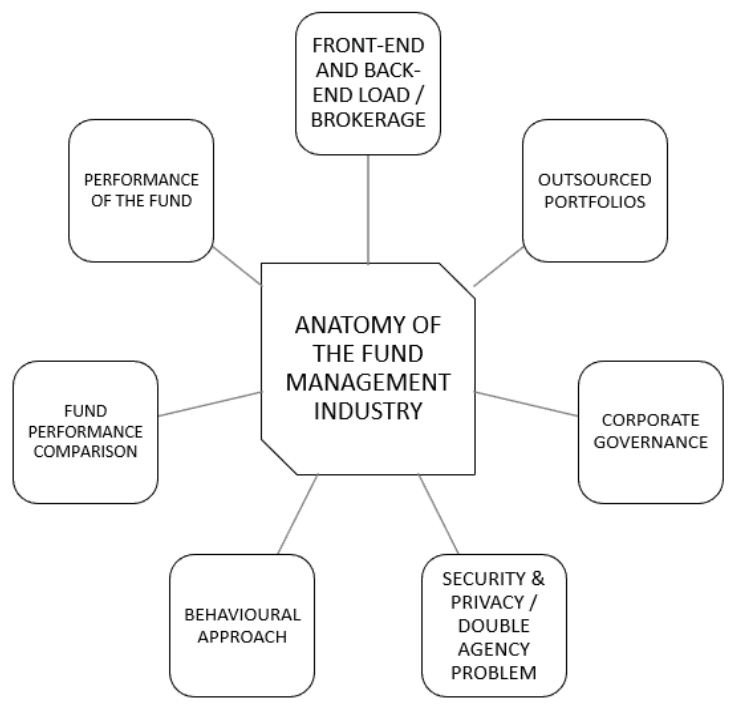

Figure 1. Research framework.

\subsubsection{Front-end and Back-end Load / Brokerage}

When an investor enters a fund, they pay a front-end load, which is a one-time fee charged by the fund. A similar back-end load gets charged on exit from the fund.

Brokerage is a percentage of the total transaction value entered, which is charged by a middle-man (broker) for executing your transaction in the market on your behalf.

\subsubsection{Outsourced Portfolios}

A lot of times, because investment companies do not have enough resources to handle their assets under management (AUM), they may outsource a part of the funds to an external manager for a specified period on a contractual basis. These are outsourced portfolios- where the management is external to the investment company.

\subsubsection{Corporate Governance}

Corporate governance refers to the rules and regulations that the business follows. It affects the internal and external processes that the company undertakes in everyday work. It interests all the stakeholders, specifically the investors. This refers to the hierarchy in the company, the rules they follow in working, the practices of reporting, compensation structures, reconciliation of conflicts, and handling of implicit contracts.

\subsubsection{Security \& Privacy / Double Agency Problem}

Information is today's oil. It needs to get guarded carefully. The companies receive a lot of financial information from clients, and therefore the question of confidentiality and trust comes into the picture. One wrong step can be very costly (Sirisomboonsuk, P., Gu, V. C., Cao, 2018).

The double agency problem refers to the conflict for managers, whether they should act in the interest of the client or themselves and the company. It may affect their decision-making process and ethics, followed by the company employees.

\subsubsection{Behavioral Approach}

Investor behavior repeats in patterns when past data is analyzed. This pattern also is seen when investors set terms for investments in front of the managers. It includes trends like social investing, passive assets, and risk-averse instruments. Socially responsible investing funds perform better in the pre- and post-financial crisis periods but underperform during the financial crisis period Belghitar, Y., Clark, E., \& Deshmukh, N. 2017). 


\subsubsection{Fund Performance Comparison}

Investors compare performance across options while picking a fund to invest in. They may judge their choices based on factors like AUM, leverage, level of risk involved, and asset class allocation.

\subsubsection{Fund Performance Measurement}

Measurement of the returns generated portrays how well the investment got used. It refers to the base on which the return is judged.

\subsection{Problems Associated with the Factors}

\subsubsection{Front-end and Back-end Load / Brokerage}

Investment companies have operating costs that include administration, salaries, rent, maintenance, and selling. These costs, like administration and custodian fees, are charged more than load payments made by investors while entering the fund. These expenses are one-time but are not considered in the indication of the true annual expense charges borne by the investor in all. This, in turn, weighs down the return passed onto the owner (Antón, M., Ederer, F., Giné, M., 2018).

Brokerage gets charged on every transaction the fund undertakes, and this cost gets indirectly passed onto the investors as lower return distribution or higher charges (Fraś, A., 2018).

These costs are many-a-times not mentioned in the IPS, and therefore, investors never anticipate them. Even though the costs are a small percentage of the AUM, they turn out to reduce the returns passed onto the investors.

Dynamic brokerages and proprietary research provided by brokers is often not disclosed to investors who may build up costs.

\subsubsection{Outsourced Portfolios}

MF businesses often outsource the management of small accounts to external managers, and any underperformance leads to the costs being borne by other funds within the business.

There are times when external managers might not have to follow the businesses' compliance/governance rules and may lead to potential breaches in terms of leverage, type of assets bought, and disclosures.

Due to legal terms of the contract and any discrepancies, there have been times when external managers did not have to pass on the full return to the business leading to lag in overall performance.

There lies confusion about whether managers should act in the interest of the business by charging more fees or for the investors by magnifying returns.

\subsubsection{Corporate Governance}

There is a lack of a robust disclosure framework when it comes to investment funds. Lack of information leads to confusion in the minds of investors. There may be breaches of investment terms by managers in the year, but because the investor only gets quarterly reports, they may not be aware of such transactions.

Insider trading is practiced but never reported. Businesses that manage multiple accounts may trade amongst them to show higher returns at the end of a financial year for accounting and tax purposes (Arjaliès, D. L., Grant, P., 2017). Strategic allocation in sub-advised funds is not a part of the performance, which might not go well with the investment objective and might also lead to underperformance.

\subsubsection{Security \& Privacy / Double Agency Problem}

Funds that allow managers to cross-sell may end up with unequal aggregated trades with costs in favor of clients. Performance-based incentives may lead managers to favor MFs over other accounts because of AUM and the magnitude of returns generated yearly. The leverage involved in hedge funds attracts managers for the large outperformance bonus (Keswani, A., Miguel, A. F., \& Ramos, S. B., 2016). In an active fund management industry, the performance and size depend on its competitiveness (concentration). Under plausible assumptions, as industry concentration decreases, it impacts fund managers' incentives adversely (Feldman, D., Saxena, K., \& Xu, J. 2020).

Companies that manage multiple types of accounts or have the same managers for different accounts may lead to a breach of confidentiality and IPR when it comes to funding and investor information. The existence of a high watermark in fund performance leads to indirect incentives, and sometimes managers may invest in risky assets only because it gets them commissions. 


\subsubsection{Behavioral Approach}

Investors have become increasingly aware of the ESC (Economic, Social, and Cultural) approach and demand investments that benefit society (Arjaliès, D. L., \& Bansal, P. 2018). They are moving towards passive growth investments, compelling funds to change their investment styles. Trends like liquidity, digital trading platforms, and securitization are taking over. The new set of skills is being garnered by managers to make sure they generate an above benchmark return because they need performance to attract potential investors. The investment horizon is moving from long term to medium term with a rise in alternative investments (Dong, 2020).

\subsubsection{Fund Performance Comparison}

Cross-fund performance comparison takes place based on the amount of returns generated, which may not always be the best indicator. The existence of conflicts of interest may improve fund performance when it comes to the selection of investments and analysis of their quality. Also, there is a lack of a standard measure to compare the performance of multiple funds within the same business, or in the industry, availability of such comparison might help investors in making better choices. Different funds involve differences based on AUM, Leverage/ level of risk, Investment horizon, Benchmarks, and Quality of management.

\subsubsection{Fund Performance Measurement}

There is no set base on which the performance of the fund gets calculated. Multiple factors affect fund performance, and there is no sure way of telling if they have positively or negatively affected the results (Haslem, J. A., 2016). The standard performance factors used to suffer from biases when it comes to weight allocation and correlation to betas. A fund's performance may be underestimated in the periods when its self-reported benchmark index generates negative alphas (Feldman, 2020). There is concern around the adequacy of the prospectus benchmarks given the fund's investment style and objectives. 


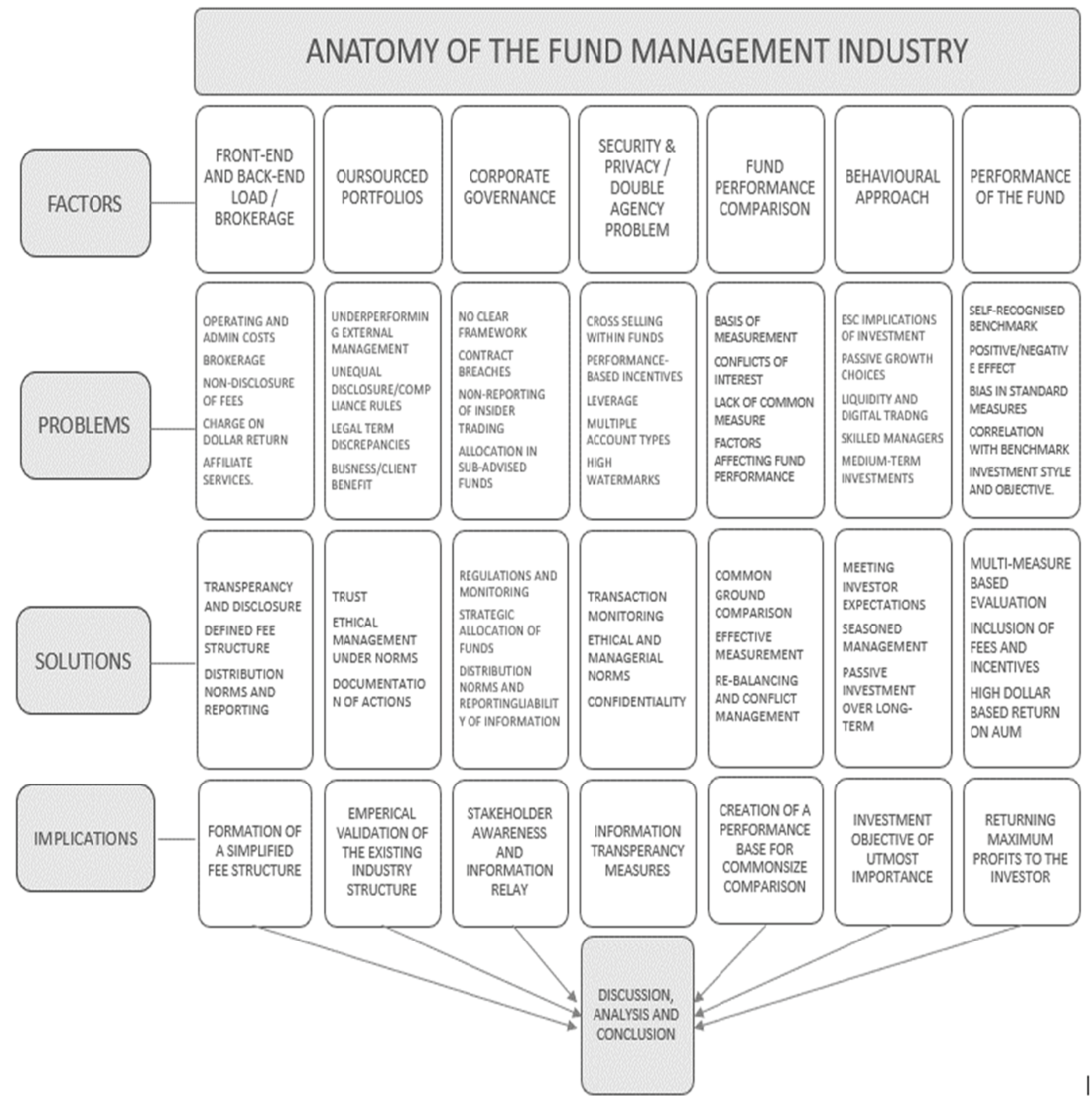

Figure 2. Problems, Solutions, and Implications

\subsection{Possible Solutions}

\subsubsection{Front-end and Back-End Load / Brokerage}

The first step in addressing this issue is transparency. Charges should be all-inclusive and structured to bring about clarity in the working of the fund. When funds put down all fees and terms on paper, disclosure ceases to be a problem. This will help investors as well as the company control expenses (Bryant, L. L., Butler, M., \& Cao, Z.,2018).

Different share classes do not represent different fundamental investments - only how investors pay the brokerage should either be a part of the investment plan or get disclosed every time they get undertaken. Charges being shows as a percentage of AUM reflect an accurate picture of the returns turned towards payments, Includes expenses, fees as well as incentives (Fraś, A., 2018). Structures such as affiliate services and dynamic brokerage should either be a part of the investment plan or disclosed every time they get undertaken. 


\subsubsection{Outsourced Portfolios}

Outsourcing of accounts should be undertaken when the managers are trustworthy. A robust set of ethics and disclosure norms should be set on paper to make sure that investor interest is protected.

There should be limitations in terms of leverage undertaken, level of autonomy, and asset quality. A set fee-based structure should define the relationship between the fund and the external manager. Investor interest must take priority every time, and covenants can be set up to make sure this happens.

\subsubsection{Corporate Governance}

Disclosures need to be justified in terms of the information being passed onto investors (Arjaliès, D. L., Grant, P., 2017). This will avoid any doubt or confusion. Managers need to regularly monitor their positions to make sure they do not breach any limits. Funds should take steps to make sure that no insider-trading is unfavorable for the market and the investor. Sub-advised funds should make sure that the strategic allocation is considered during performance measurement to avoid any lags. Reporting should make sure that project reports are available in a timely fashion and contain relevant and reliable information that supported the organization's decision-making processes.

\subsubsection{Security \& Privacy / Double Agency Problem}

Funds with common managers need to make sure there are not cross-selling, and this is where transaction monitoring systems can help (Moreno, D., Rodriguez, R., \& Zambrana, R, 2018). There should be levels of performance-based incentives and outperformance fees to motivate managers and keep leverage in check. It's also important a framework for the maintenance of confidentiality needs to be put in place. Commission-based products need full disclosure, and watermarks need to get moderately leveled.

\subsubsection{Behavioral Approach}

It is vital to make sure that funds meet investor expectations in terms of asset quality, level of risk, and investment horizon (Cuthbertson, K., Nitzsche, D., \& O'Sullivan, N., 2016). With more transparency, companies need to make sure they stay within their boundaries. Today investors deem that the manager is as important as the fund when it comes to their wealth creation choices (Arjaliès, D. L., \& Bansal, P., 2018). Therefore, quality management is a must. Passive investments will make sure that capital grows over time. Excellent performance YoY will attract investors.

\subsubsection{Fund Performance Comparison}

Fund comparison should be based upon common ground and for similar-sized capital. For measuring performance, the results need to get organized to each factor on the result achieved in that period. Fund performance is also influenced by tracking error and expenses- which need to be considered in comparisons also, and the Funds need to be re-balanced to make sure that they meet their objective. Conflicts of interest need to get monitored to make sure they only yield positive returns.

\subsubsection{Fund Performance Measurement}

A multi-measure-based calculation will give an accurate estimation of the performance of the fund. Management fees and incentives need to get included in all the calculations. The performance now includes a structure that currently consists of governance, economic \& social factors, and a system focus. The return generated needs to be stated on a per-share basis to make analysis easier.

\subsection{Implications of Factors}

From the literature review and practical perspective, the four major issues identified include

- $\quad$ Agency of the fund and it's management.

- Excessive amounts of fees often negate the returns generated.

- $\quad$ Absence of measurement instruments

- $\quad$ Privacy of the information and lack of customer trust

The formation of a simplified fee structure is the first step the industry can take to make things better. The inclusion of the structure in the investment policy statement (IPS) will ensure that investors get well informed of all the costs associated with investing in an investment fund.

Next comes clarity in terms of all the decision making that is associated with the fund. Especially in sub-advised funds, there needs to be a clear hierarchy that defines responsibility when it comes to investment vehicle selection. Stakeholder awareness and the information relay within the firm will become faster this way, leading to better 
decision-making. A well-thought-out strategy will pave the way for a smooth investment plan.

Information needs to get safeguarded to avoid any leaks or misuse. Making investment objectives a top priority will also help managers better plan their alternatives. At last, what matters is the return that the owner gets out of the investments made. The asset-mix should get intended in a way that leverages the maximum available funds, and the performance outperforms the market.

\section{Discussion, Analysis, and Outcome}

Even though the asset management industry is not very young, it still has a long way to go. All stakeholders have a role to play to develop it further for the betterment of the economies. The ever-increasing number of players will also bring about a positive change.

\subsection{Ethics}

For individual/corporation to trust another professional with their wealth says about ethics that are required by profession. Also, this industry runs majorly on past performance. Any discrepancies in the previous results impact adversely.

\subsection{Seasoned Management}

Experience in the human resources of the company speaks highly of knowledge. An investor would invest with an experienced manager even if it means they might earn lower returns (Berk, J. B., \& Van Binsbergen, J. H., 2015).

\subsection{Investor Awareness}

Today, investors are aware of the events happening in the markets, which acts as a boost for the managers to perform better over time. They know they are answerable for all their actions taken while picking from the various instruments available in the market.

\subsection{Technological Changes}

Digitalization in the industry, there is a need for utmost accuracy leading to improvements in the offerings, Investors also gets a variety of investments to choose.

\section{Research Implications}

There are multiple findings from this research. The critical factor here is the structure of fees getting charged. Transparency and information are the key elements. Another variable, regulation, requires the immediate attention of all parties. As more countries structure their own rules, more organizations will be adopting their processes to the regulations (Mansor, F., Bhatti, M. I., \& Ariff, M., 2015). As more organizations comply with the rules, there can be an improvement in the security of data, and this may become a standard throughout the modern world.

Another area that requires attention is the existence of a joint base or the creation of an agency that may help in recognizing the quality of earnings getting generated in the industry (something like what a credit rating agency is in the debt market).

\section{Conclusion}

Global fund management firms like the Vanguard Group, Pacific Investment Management Company, LLC, BlackRock, Inc, Fidelity Investments and Invesco Ltd are a few of them committing to making their working more investor-friendly to demonstrate their potential.

Increasing client demand for lower fees, new regulation, and closer scrutiny of the social value of the investment management industry itself are some of the significant issues they face. Innovation is driving another change with less dependence on humans. They face a downward fee- pressure which is forcing them to optimize their workings. Active management remains to be a considerable part of the companies. They need supervision and transformation.

Another aspect is the level of risk involved. It includes risks like Financial risk, Operation risk, Counter-party risk, and Foreign exchange risk.

Inclusion of these leads to a higher expectation in exchange for undertaking this risk. Better asset-allocation in terms of a defined instrument structure calls for constant changes in the portfolio to maintain the mix (Fichtner, J., Heemskerk, E. M., \& Garcia-Bernardo, J., 2017). Another battle to conquer is being able to win retail clients. As the number of UHNIs in the world increases every day, funds target them by offering lucrative returns. A more significant AUM calls for economies of scale and more considerable income. Compared with younger funds, older funds have more severe decreasing returns to scale as the industry size increases Chong, T. T.-L., Lee, N., \& Sio, C.-I. 2020). 
Regulators are working towards standardization- which is a long-term process. Bloomberg says, "Whatever their product focus, asset managers today face a future in which achieving growth will require firms to differentiate themselves by demonstrating value through marketing campaigns, sales activity, and pricing. In many cases, says BCG, -winning managers will gain an advantage by developing and deploying advanced capabilities in data-driven decision-making" (Pástor, L., Stambaugh, R. F., \& Taylor, L. A. 2015).

New research from Greenwich Associates shows that top-notch persuasion and presentation skills will be more critical than ever for investment managers seeking to build relationships with consultants, who are tightening their control of institutional assets. Performance just might re-invigorate active management- support the asset managers again.

\section{Scope for Future Research}

This research looks at the investment management industry or general. Different offerings across the markets and their structures is another big area to explore. Besides, further analysis can narrow the study down to specific instruments and departments, such as equities, where customer data is collected extensively for data analytics or alternative assets, which possess potential quality information that will help in the further development of the markets. This paper is based on secondary data. Future research can make use of primary data through surveys or interviews.

The companies involved are continuously evolving to keep up with the advancements in technology and changes in society. Also, more and more countries will follow suit and form their structures to suit the current situation better. There is a scope for future research on these topics.

\section{References}

Ahmad, Zamri., Ibrahim, Haslindar. \& Tuyon, Jasman. (2018). Asian Academy of Management Journal of Accounting \& Finance, 14(2), 65-102. https://doi.org/10.21315/aamjaf2018.14.2.4

Andonov, A., Eichholtz, P. \& Kok, N. (2016). Intermediated investment management in private markets: Evidence from pension fund investments in real estate. Journal of Financial Markets, 22, 73-103. https://doi.org/10.1016/j.finmar.2014.11.002

Antón, M., Ederer, F., Giné, M. \& Schmalz, M. C. (2018). Common ownership, competition, and top management incentives. Ross School of Business Paper, (1328).

Arjaliès, D. L. \& Bansal, P. (2018). Beyond numbers: How investment managers accommodate societal issues in financial decisions. Organization Studies, 39(5-6), 691-719. https://doi.org/10.1177/0170840618765028

Arjaliès, D. L., Grant, P., Hardie, I., MacKenzie, D. \& Svetlova, E. (2017). Chains of finance: How investment management is shaped. Oxford University Press.https://doi.org/10.1093/oso/9780198802945.001.0001

Berk, J. B. \& Van Binsbergen, J. H. (2015). Measuring skill in the mutual fund industry. Journal of Financial Economics, 118(1), 1-20.https://doi.org/10.1016/j.jfineco.2015.05.002

Brown, S. \& Pomerantz, S. (2018). Some Clarity on Mutual Fund Fees. U. Pa. J. Bus. L., $20,767$. https://doi.org/10.2139/ssrn.3050589

Bryant, L. L., Butler, M. \& Cao, Z. (2018). Mutual Fund Fee Structures and Broker Compensation. Annals of Economics and Finance, 19(1), 197-211.

Belghitar, Y., Clark, E. \& Deshmukh, N. (2017). Importance of the Fund Management Company in the Performance of Socially Responsible Mutual Funds. Journal of Financial Research, 40(3), 349-367. https://doi.org/10.1111/jfir.12127

Bengtsson, E. (2014). Fund Management and Systemic Risk - Lessons from the Global Financial Crisis. Financial Markets, Institutions \& Instruments, 23(2), 101-124. https://doi.org/10.1111/fmii.12016

Chong, T. T.-L., Lee, N. \& Sio, C.-I. (2020). Threshold effect of scale and skill in active mutual fund management. North American Journal of Economics \& Finance, 51, N.PAG. https://doi.org/10.1016/j.najef.2019.101079

Chen Ying, Zhang Xiaoqiang, Yang Chen, Shan Shuang. Economic Computation \& Economic Cybernetics Studies \& Research, 52(1), 143-160. https://doi.org/10.24818/18423264/52.1.18.09

Cremers, M., Ferreira, M. A., Matos, P. \& Starks, L. (2016). Indexing and active fund management: International evidence. Journal of Financial Economics, 120(3), 539-560. https://doi.org/10.1016/j.jfineco.2016.02.008

Cuthbertson, K., Nitzsche, D. \& O'Sullivan, N. (2016). A review of behavioural and management effects in mutual fund performance. International Review of Financial Analysis, 44, 162-176. 
https://doi.org/10.1016/j.irfa.2016.01.016

Del Guercio, D., Genc, E. \& Tran, H. (2018). Playing favorites: Conflicts of interest in mutual fund management. Journal of Financial Economics, 128(3), 535-557. https://doi.org/10.1016/j.jfineco.2017.04.012

Duanmu, J., Malakhov, A. \& McCumber, W. R. (2018). Beta Active Hedge Fund Management. Journal of Financial and Quantitative Analysis, 53(6), 2525-2558. Energy performance contracting. https://doi.org/10.1017/S0022109018000388

Dong, F. \& Doukas, J. A. (2020). When fund management skill is more valuable? European Financial Management, 26(2), 455-502. https://doi.org/10.1016/j.jfineco.2019.08.009

Farinella, J. \& Kubicki, R. (2018). The Performance of Exchange Traded Funds and Mutual Funds. Journal of Accounting \& Finance (2158-3625), 18(4). https://doi.org/10.33423/jaf.v18i4.423

Ferreira, M. A., Matos, P. \& Pires, P. (2018). Asset management within commercial banking groups: International evidence. The Journal of Finance, 73(5), 2181-2227. https://doi.org/10.1111/jofi.12702

Fichtner, J., Heemskerk, E. M. \& Garcia-Bernardo, J. (2017). Hidden power of the Big Three? Passive index funds, re-concentration of corporate ownership, and new financial risk. Business and Politics, 19(2), 298-326. https://doi.org/10.1017/bap.2017.6

Fraś, A. (2018). Are the Highest Mutual Fund Fees Justified by Their Performance? Problemy Zarzadzania, 16(2 (74)), 62-73. https://doi.org/10.7172/1644-9584.74.3

Fung, W., Hsieh, D., Naik, N. \& Teo, M. (2016). Growing the asset management franchise: evidence from hedge fund firms.

Feldman, D., Saxena, K. \& Xu, J. (2020). Is the active fund management industry concentrated enough? Journal of Financial Economics, 136(1), 23-43. https://doi.org/10.1016/j.jfineco.2019.08.009

Gilbert, M. (2020). Fund Management's Dismal Drama Needn't Be a Crisis: Mark Gilbert. Bloomberg.Com, N.PAG.

Goetzmann, W. N., Ingersoll Jr, J. E. \& Ross, S. A. (2013). High - water marks and hedge fund management contracts. The Journal of Finance, 58(4), 1685-1718. https://doi.org/10.1111/1540-6261.00581

Hsiu-Lang Chen, Jegadeesh, N. \& Wermers, R. (2000). The Value of Active Mutual Fund Management: An Examination of the Stockholdings and Trades of Fund Managers. Journal of Financial \& Quantitative Analysis, 35(3), 343-368. https://doi-org.spjain.idm.oclc.org/10.2307/2676208

Haslem, J. A. (2016). Issues in Mutual Fund Distribution. Journal of Wealth Management, 18(4), 36-58.suba https://doi.org/10.3905/jwm.2016.18.4.036

Hawley, J. P. \& Lukomnik, J. (2018). The third, system stage of corporate governance: Why institutional investors need to move beyond modern portfolio theory. System Stage of Corporate Governance: Why Institutional Investors Need to Move Beyond Modern Portfolio Theory (February 21, 2018). https://doi.org/10.2139/ssrn.3127767

Henriksson, R., Livnat, J., Pfeifer, P. \& Stumpp, M. (2019). Integrating ESG in Portfolio Construction. The Journal of Portfolio Management, 45(4), 67-81. https://doi.org/10.3905/jpm.2019.45.4.067

Kahn, R. N. \& Lemmon, M. (2016). The asset manager's dilemma: How smart beta is disrupting the investment management industry. Financial Analysts Journal, 72(1), 15-20. https://doi.org/10.2469/faj.v72.n1.1

Keswani, A., Miguel, A. F. \& Ramos, S. B. (2016). Mutual Fund Size versus Fees: When big boys become bad boys. FMA-2016 Working Paper.

Lapatto, A. \& Puttonen, V. (2018). Life after death: acquired fund performance. Managerial Finance, 44(3), 389-402. https://doi.org/10.1108/MF-02-2017-0031

Ma, L., Tang, Y. \& Gómez, J. P. (2019). Portfolio manager compensation in the US mutual fund industry. The Journal of Finance, 74(2), 587-638. https://doi.org/10.1111/jofi.12749

Mansor, F., Bhatti, M. I. \& Ariff, M. (2015). New evidence on the impact of fees on mutual fund performance of two types of funds. Journal of International Financial Markets, Institutions and Money, 35, 102-115. https://doi.org/10.1016/j.intfin.2014.12.009

Matallín-Sáez, J. C., Soler-Domínguez, A. \& Tortosa-Ausina, E. (2019). Does active management add value? New 
evidence from a quantile regression approach. Journal of the Operational Research Society, 1-18. https://doi.org/10.1080/01605682.2019.1612549

Matallín-Sáez, J. C., Soler-Domínguez, A., Tortosa-Ausina, E. \& de Mingo-López, D. V. (2019). Ethical strategy focus and mutual fund management: Performance and persistence. Journal of Cleaner Production, 213, 618-633. https://doi.org/10.1016/j.jclepro.2018.12.130

Mateus, I. B., Mateus, C. \& Todorovic, N. (2018). Review of new trends in the literature on factor models and mutual fund performance. International Review of Financial Analysis. https://doi.org/10.2139/ssrn.3273374

Mokhtarian, E. \& Lindgren, A. (2018). Rise of the Crypto Hedge Fund: Operational Issues and Best Practices for an Emergent Investment Industry. Stan. JL Bus. \& Fin., 23, 112.

Moreno, D., Rodriguez, R. \& Zambrana, R. (2018). Management sub-advising in the mutual fund industry. Journal of Financial Economics, 127(3), 567-587. https://doi.org/10.1016/j.jfineco.2018.01.004

O'Neal, E. S. (1999). Mutual fund share classes and broker incentives. Financial Analysts Journal, 55(5), 76-87. https://doi.org/10.2469/faj.v55.n5.2302

Pástor, L., Stambaugh, R. F. \& Taylor, L. A. (2015). Scale and skill in active management. Journal of Financial Economics, 116(1), 23-45. https://doi.org/10.1016/j.jfineco.2014.11.008

Phalippou, L., Rauch, C. \& Umber, M. (2018). Private equity portfolio company fees. Journal of Financial Economics, 129(3), 559-585. https://doi.org/10.1016/j.jfineco.2018.05.010

Sirisomboonsuk, P., Gu, V. C., Cao, R. Q. \& Burns, J. R. (2018). Relationships between project governance and information technology governance and their impact on project performance. International journal of project management, 36(2), 287-300 https://doi.org/10.1016/j.ijproman.2017.10.003

Tchamyou, V. S., Asongu, S. A. \& C. Nwachukwu, J. (2018). Effects of asymmetric information on market timing in the mutual fund industry. International Journal of Managerial Finance, 14(5), 542-557. https://doi.org/10.1108/IJMF-09-2017-0187

Wang, P. (2018). Portfolio Pumping in Mutual Fund Families. https://doi.org/10.2139/ssrn.2933600 